\title{
What Do You Want from Us? Evaluating Student Interest in Technology-Based Services in Academic Libraries
}

\section{Susan Elkins, Soo-yeon Hwang, Dianna Kim, Tyler Manolovitz, Kat Landry Mueller, and Erin Owens}

Following two previous studies in 2010 and 2013, this study intends to identify current trends of Sam Houston State University students' technology and communication needs and preferences regarding library services and resources. Drawing comparisons to two previous local studies and national data sets, such as those from Pew Internet Research and the EDUCAUSE Center for Analysis and Research (ECAR), the findings revealed, among other things, a decline in tablet usage and interest, continued need for library computers, and a complex relationship between social media usage and engagement with the library. The results of this survey will inform and guide the library and the profession to most efficiently and effectively offer desired library services and engage students on appropriate social media platforms.

\section{Introduction}

Institutions of higher education are increasingly visible and interacting with students in online settings such as social media. Studies of the local university community provide continued direction of academic libraries' digital content creation and investment in social media platforms, as well as to inform librarians of opportunities for ongoing active engagement. Due to the pervasiveness of social media and digital devices in many aspects of daily life, librarians at Sam Houston State University (SHSU) sought to build upon the library's 2010 and 2013 studies by gathering current and relevant information on students' needs and preferences concerning technology and communication. SHSU is a Carnegie Research Doctoral university located about an hour north of the [city] metropolitan area, and the current student population has a large percentage of first-generation, commuter, and nontraditional students. While the 2013 survey revealed that tablets, such as the iPad, had not altered the educational technology landscape as much as anticipated, reviewing students' use of mobile devices and computers during their tenure at SHSU is still valuable - for both recording longitudinal institutional data and providing library services best suited to SHSU's community of users. Additionally, the

Susan Elkins, Soo-yeon Hwang, and Dianna Kim are Assistant Professors; Tyler Manolovitz is Clinical Assistant Professor; and Kat Landry Mueller and Erin Owens are Associate Professors; all at Sam Houston State University; email: selkins@shsu.edu,syhwang@shsu.edu,dlk011@shsu.edu, tyler@shsu.edu,klmueller@shsu.edu, eowens@shsu. edu. (C) 2020 by Susan Elkins, Soo-yeon Hwang, Dianna Kim, Tyler Manolovitz, Kat Landry Mueller, and Erin Owens 
researchers wished to gain greater insight into SHSU students' perceptions and predilections for communication with the library on current and emerging social media channels.

\section{Literature Review}

Libraries have been looking to find their place in the social media landscape since its inception. As far back as 2006-2007, libraries have been exploring MySpace and Facebook to serve and connect with their populations. ${ }^{1}$ That desire to harness social media as a beneficial tool has increased almost as fast as the technology itself, although libraries continue to study and adapt to maximize benefits. According to Pew Research Center data, 5 percent of American adults used at least one social media site in 2005, but that ballooned to 46 percent in 2010, 65 percent in 2015, and topped out at 69 percent in 2018. ${ }^{2}$ However, among young adults, the target audience for most academic libraries, these numbers soared even higher: 7 percent in 2005, 80 percent in 2010, 90 percent in 2015, with a small dip to 88 percent in 2018. ${ }^{3}$ With 9 out of 10 young adults reporting social media use, it only makes sense for academic libraries to try to capitalize on these trends.

Not only do Americans use social media at a very high rate, but many rank social media as a very important facet of their lives that would be difficult to give up. According to Pew, 40 percent of all social media users say it would be hard to give up, with 51 percent of young adults (18 to 24) reporting the same (2018). ${ }^{4}$ A survey by Taylor and Francis in 2014 found that more than 70 percent of respondents felt that social media is important. ${ }^{5}$ With such wide usage and importance of social media, libraries have eagerly taken advantage of these tools to reach their constituents.

In 2012, according to one study, 71 percent of libraries were already using social media in some capacity. ${ }^{6}$ According to the Taylor and Francis survey, 61 percent of respondents had at least one social media account for at least three years, and 68 percent were managing up to four separate accounts. ${ }^{7}$ Likewise, Collins and Quan-Haase found that two-thirds of the Ontario academic libraries in their study were active on at least one social media platform. ${ }^{8}$ Clearly, libraries have taken advantage of social media services to promote their services. However, social media is a broad term that encompasses an increasingly difficult-to-determine number of platforms: Facebook, Twitter, Instagram, Snapchat, and others. Particularly problematic is determining the services in which libraries should invest their resources.

Despite a slight dip in popularity, Facebook continues to be the most dominant social media platform, with 68 percent reported usage among American adults, of which approximately 75 percent report using Facebook daily. ${ }^{9}$ Notably, though, the younger Facebook users have reported deleting the Facebook app from their phones entirely. The Pew Research Center found in their 2018 report that 44 percent of users aged 18-29 had done just that, in comparison to only 12 percent of users aged 65 and older. ${ }^{10}$

Overall, though, younger adults spend more time on social media and use more social media platforms. Among adults between 18 and 24, 78 percent use Snapchat (71\% visiting multiple times per day), 71 percent use Instagram, and 45 percent use Twitter. ${ }^{11}$ Different segments of the population tend to use different social media platforms as well. Pinterest is popular with women ( $41 \%$ women versus $16 \%$ of men), LinkedIn is popular with college graduates ( $50 \%$ with a degree versus $9 \%$ without), and WhatsApp is popular with Hispanics (49\% Hispanics, versus $21 \%$ blacks and $14 \%$ whites). ${ }^{12}$ This falls in line with findings by Collins and Quan-Haase that suggest the "geographical location of an academic library 
potentially has an impact on the adoption and usage patterns of social media." ${ }^{13}$ To put it simply and unsurprisingly, different populations desire and use different platforms and services.

With so many social media platforms available, and some much more popular with specific segments of the population, libraries must not only determine if they should join the fray, but also, where to direct their resources and efforts. A study of social media use by Alaskan libraries found that Facebook was the most popular platform used by libraries; surprisingly, however, Twitter was the second-most common, despite being a less popular platform overall. ${ }^{14}$ Collins and Quan-Haase were similarly surprised to find Twitter just as popular as Facebook. ${ }^{15}$ A study at Purdue University found results more in line with the overall Pew data, with the top five platforms being Facebook, YouTube, Snapchat, Instagram, and Twitter ${ }^{16}$ The Taylor and Francis survey found, in 2014, only 34 percent interest in Pinterest and 26 percent in Instagram. ${ }^{17}$ A study at Western Oregon University found Facebook to be the most popular, followed by a tie between Pinterest and Instagram, and then Twitter, Google+, Tumblr, and Flickr. ${ }^{18}$

When looking at investing in social media services, and to justify the cost, "...a library should ideally be able to connect the use of the service to the outcome of an activity(s) that uses the service, and the value of that outcome." ${ }^{19}$ Interestingly, despite being the most popular social media platform, Facebook might not be the best choice for libraries looking to showcase services, events, or collections to students. According to a study conducted by Hamersly Library at Western Oregon University, a 2013 change in Facebook's newsfeed algorithm significantly reduced the number of people receiving their organization's Facebook posts. ${ }^{20}$ Content that reached hundreds to thousands of followers prior to the algorithm change reached 50 or fewer afterward. ${ }^{21}$ Similarly, Hamersly Library's Facebook page "likes" have waned over the past few years, notwithstanding increases in both the amount of staff time devoted to content creation and the rate of regular posting. ${ }^{22}$

Facebook's algorithmic pitfalls do not apply to Twitter, however, and The University of Liverpool Library found that the use of this platform was quite successful for the promotion of library events. ${ }^{23}$ While maintaining a presence on Facebook, Instagram, and Twitter, the Liverpool Library found Twitter to be the most rapidly growing account, with the number of followers tripling between 2013 and 2016. ${ }^{24}$

However, there has been a migration by teens, young adults, and first- and second-year college students to increasingly private and interactive platforms. ${ }^{25}$ Therefore, Snapchat and Instagram, with their photo- and video-sharing capabilities, are being analyzed by libraries as a way to reach this demographic. ${ }^{26}$ In her study of 11 library professionals from nine libraries, Paige Alfonzo found that the primary reason libraries use social media or consider adding a platform is to connect or communicate with patrons. When Rice Lake Public Library noticed a decline in their interactions with patrons in their twenties on Facebook, they began using Snapchat to reach this demographic. ${ }^{27}$ Orilla Public Library stated: "Right now teens are using Snapchat, so that's what's working." ${ }^{28}$ Austin Community College noted that they began using Instagram because the platform capabilities permitted them to "communicate something new and different... literally paint a picture of what the inside of the library looks like and add a lighthearted 'human' element." 29 Making an effort to reach patrons on the platforms they are using can be quite worthwhile. In only a year and a half, the Topeka \& Shawnee County Public Library gained 1,000 followers on Instagram. ${ }^{30}$ 
Another important question to address is whether students actually want libraries on social media at all. In 2008, Chu and Meulemans found that students were uncomfortable using social media to connect with academic personnel, preferring email instead. ${ }^{31}$ Burhanna, in 2009, believed an emphasis in social media would likely be a misallocation of resources. ${ }^{32}$ Quan-Haase and Young reported in 2010 that students used social media mostly for nonacademic purposes. ${ }^{33}$ As social media has gained popularity, and libraries have adapted their social media use, these opinions have softened. Part of this may likely be the difference between the library existing on social media and actively engaging with students on social media. Howard, Huber, Carter, and Moore found that 57 percent of respondents were either extremely or somewhat likely to follow the library. ${ }^{34}$ In addition, when asked which platforms they thought a library should use, respondents said Facebook (82\%), Instagram (55\%), Twitter (40\%), Snapchat (34\%), and YouTube (29\%). ${ }^{35}$ Cassidy et al. found Facebook (71\%), Twitter (56\% of current Twitter users), Google+ (35\%), and Pinterest (32\%). ${ }^{36}$ Brookbank found that students were most interested in the library using Twitter $(40 \%)$, despite its being only the fourth-most popular tool among the student population. ${ }^{37}$ Instagram was also a very popular suggestion, followed by Pinterest. ${ }^{38}$

While libraries experimented with different types of services in the early days of social media adoption, they seem to have found a comfort level with certain services. As expressed by Taylor and Francis, "Social media is used by libraries to deliver a blend of customer service, news and updates, content/collection promotion, dissemination of the institutions' research output, provision of educational tools and resources and for building relationships both within and outside of the institution." ${ }^{39}$ Findings by Collins and Quan-Haase seem to agree with this assertion, noting that, despite their expectation that libraries promote digital resources, "[1]ibraries primarily posted information on activities, events, and resources found in the physical library." 40 Kingsley concurred in a study of Alaskan libraries by finding that social media is used primarily for promoting library news and events, resources, and services. ${ }^{41}$ In other words, libraries seem to use social media as more of a marketing tool than for direct patron interaction, outreach, or research assistance.

The next logical question is, what kind of information do students want to see from libraries on social media? Burgert, Nann, and Sterling found that students primarily sought event information (34\%) and leisure content, including quotes and graphics (28\%). ${ }^{42}$ Interestingly, resource links and educational material were the least desirable, at 20 and 18 percent, respectively. ${ }^{43}$ Brookbank found that students are most interested in library posts related to campuswide information/events (88\%), research techniques and tips $(88 \%)$, and library logistics" (87\%). ${ }^{44}$ Stvilia and Gibradze found that students preferred posts related to library hours/facility issues, study support tips, and event information. ${ }^{45}$ Howard, Huber, Carter, and Moore found students were most interested in "library logistics" relating to library hours and events. ${ }^{46}$

Looking beyond social media to the hardware that students use, the literature shows digital technology is increasingly necessary for success in higher education. According to EDUCAUSE Center for Analysis and Research (ECAR), students have identified four technologies as "most important to their student success." ${ }^{47}$ Of these four technologies (smartphones, laptops, desktops, and hybrids), less than 1 percent of students reported having no access at all. ${ }^{48}$ In total, students reported the most access to smartphones (95\%) and laptops (91\%), followed by desktops (35\%) and hybrids (11\%). With so much ownership and access - including 
59 percent of students owning two to three internet-capable devices, and 37 percent owning four or more internet-capable devices - ECAR reports that "US students now appear to have overcome the problem of digital inclusion." ${ }^{49}$ Interestingly enough, these numbers are slightly down from the 2017 study, which found 97 percent smartphone ownership, 95 percent laptop ownership, and 29 percent desktop ownership. ${ }^{50}$ The 2017 ECAR study also mentions that tablets, despite having 53 percent ownership, "appear to be falling out of favor" after dropping 7 percentage points from 2016. ${ }^{51}$ This assertion is supported by the 2018 ECAR study, which found the number falling an additional 13 points, to 40 percent, and being excluded from the core four important technologies for student success. ${ }^{52}$

Student opinions concerning the importance of devices seems to reflect ownership trends. Ninety-eight percent of students in the 2018 ECAR study reported using laptops in at least one class, and 94 percent of those surveyed regarded them as either very important or extremely important. ${ }^{3}$ Likewise, "smartphone usage and importance both increased modestly since 2017 , continuing an upward trend for the third year in a row." 54 These trends likely correlate with instructors' increased use of mobile devices in education. Such devices allow the flexibility of accessing learning materials at any time and any place. Incorporating these devices into the learning environment also increases student engagement and provides opportunities for instructors to create "rich learning content," which can have a positive effect on student success and "foster learner independence." 55

\section{Methodology}

An 87-item online survey was developed and approved by SHSU's Institutional Review Board (IRB) to assess students' perceptions and preferences for current and emerging information technologies at Sam Houston State University. The survey instrument is publicly available at https://hdl.handle.net/20.500.11875/2704. A previously used survey questionnaire was altered, and additions were made to the instrument used in the 2013 study. ${ }^{56}$ Some questions from the original survey regarding common technology such as laptops, Twitter, and mobile phones were kept the same for comparison with past study findings. In addition, new questions were added regarding technology and social media platforms that have emerged since the last survey, such as Instagram and Snapchat.

The first section of the survey evaluated students' access to computers, laptops, and tablets at home. Next, students were asked about their access to and use of smartphones, e-readers, and campus laptops. The third and largest section of the survey was about social media use, including platforms used, frequency of use, and reason for use. Students were also asked about their interest in receiving communications from the library through each platform. Finally, students were asked to provide general demographics information such as gender, age, and areas of study.

The entire survey took between 10 and 20 minutes to complete. Most respondents were not asked to answer all the questions, since some were conditional upon a respondent's usage or access to certain technologies. For example, if a respondent indicated that they did not use Twitter, they would not be asked any more questions regarding Twitter. The survey was open to all students in the fall 2017 semester via a link emailed to each student's official university email account. With the survey sent to 21,116 enrolled students, the 798 finished recorded responses provided a representative sample of sufficient size to analyze (exceeding the quantity of responses needed for a $99 \%$ confidence rate with a $5 \%$ margin of error). 
The survey was open in the Qualtrics survey software for one month, and a reminder email was sent at the halfway point. As an incentive for participation, two Amazon gift cards were offered as prizes for respondents who completed the survey and provided an email address for the drawing. Participants' email addresses were stored securely and separately from the survey results.

\section{Results}

Respondent gender skewed toward female $(74.6 \%$, versus $23.8 \%$ male; $1.6 \%$ selected either Other or Prefer not to answer). Overall university enrollment also skew female, though to a lesser degree $(62.8 \%$ versus $37.2 \%$ male). The majority of respondents $(71.9 \%)$ were born between 1993 and 2000, equating to the traditional "college age" population of approximately 17 to 24 years old; 15.3 percent were born between 1983 and 1992, and only 12.1 percent were born before 1983. This is comparable to the fall 2017 demographics of the university, in which 74 percent of students were born between 1993 and 2000, 16 percent were born between 1983 and 1992, and 9 percent were born before 1983.

Distribution across student classifications was relatively even, with the exception of a significantly lower proportion of $\mathrm{PhD}$ students (see figure 1). Representation of academic colleges was also relatively well distributed, with participation from each college: ranging from 9.7 percent (College of Fine Arts and Mass Communication) to 17.3 percent (College of Criminal Justice). More than half of respondents (58.8\%) take classes face-to-face at the main campus, while 33.3 percent take classes online, and 6.3 percent take classes at a satellite campus.

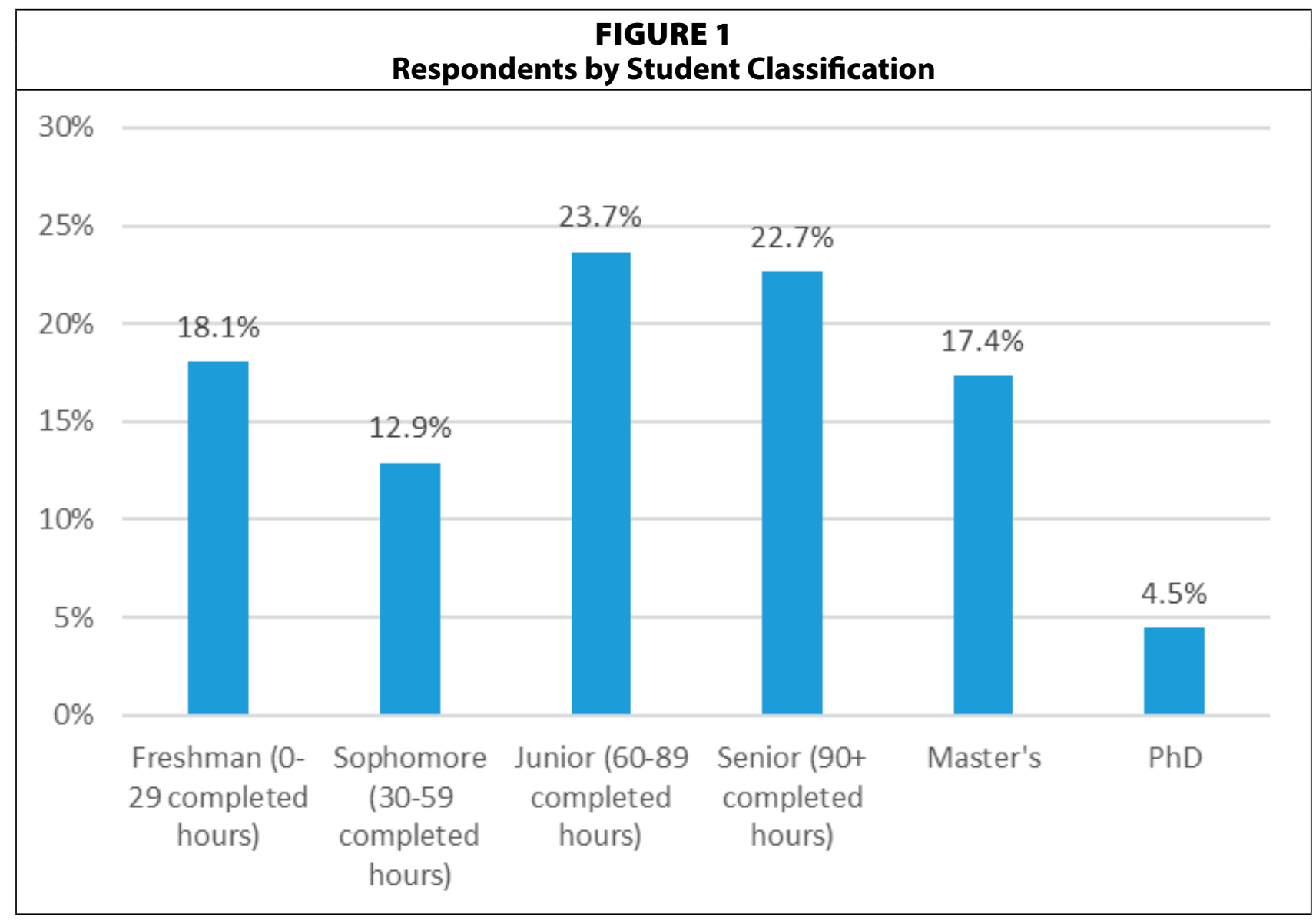




\section{Devices}

Home desktop use has fallen from 55.6 percent in 2010, to 47.3 percent in 2013, and now to 32.3 percent in 2017. More than 95.4 percent of students report using a laptop in 2017, but only 58.7 percent of them bring it to campus at least once a week, while an almost equivalent 57.8 percent report using a campus desktop computer (other than in a classroom) at least once a week. With regard to tablets such as iPads, the 2013 data showed a moderate adoption $(33.8 \%$ using) and a high interest (58\% not using but interested); only 8.2 percent reported no interest in use. However, interest in using tablets appears to have cooled with time: the 2017 data show only a slight increase in adoption (up to $43.0 \%$ using), along with a major shift from not using but interested (down to $26.6 \%$ ) to not interested (significantly increased to $30.4 \%$ ). Figure 2 shows the population saturation of each device from 2010 through 2017.

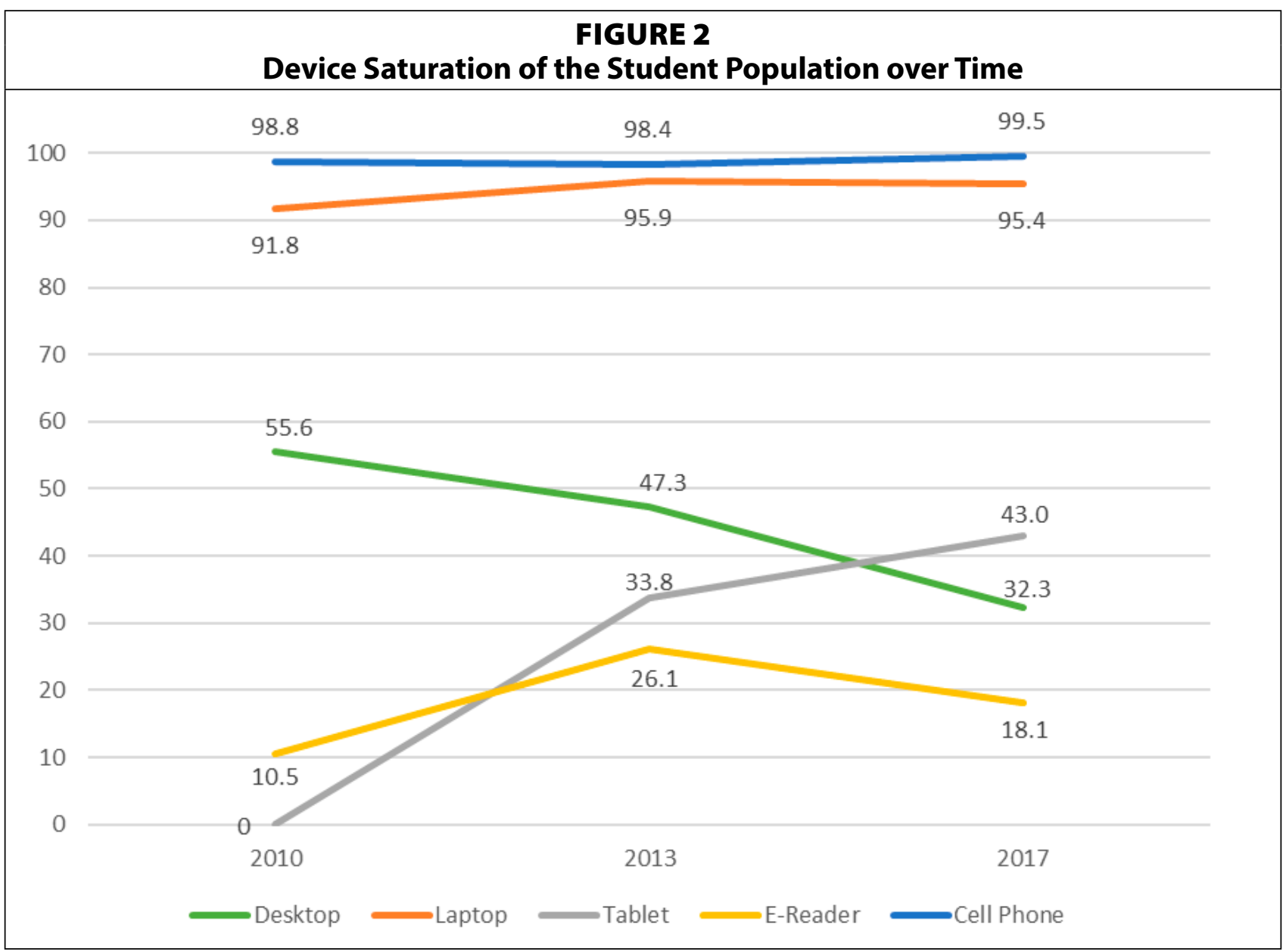

At one extreme, only a minority of students still use a dedicated e-reading device (18.1\%) or have any interest in use (18.3\%), compared to a majority 63.6 percent who have no interest in using an e-reader. At the other end of the spectrum, student adoption of cell phone technology is nearly universal at 99.5 percent, though this indicates that a small percentage of the student body still does not use this technology. Among smartphone users, the iPhone has strengthened its dominant position in 2017: 68.1 percent are iPhone users versus 30.9 percent for Android, up from a narrower margin of 44.2 percent versus 37.4 percent in 2013. Ten respondents $(1.3 \%)$ reported having cell phones but have not adopted smartphone technology. 
The data show that students rarely own just one device: zero own only a desktop, laptop, or tablet, and barely 1 percent own only a smartphone. No respondents reported ownership of zero devices. At the same time, however, most students also do not own numerous devices: only 14.07 percent own all four-smartphone, tablet, laptop, and desktop. Most students fall somewhere in the middle, with the largest segment of the population $(40.5 \%)$ owning a smartphone and a laptop. Figure 3 shows overlap in student device ownership, following a diamond-shaped matrix graph design from the 2017 ECAR Study of Undergraduate Students and Information Technology. ${ }^{57}$

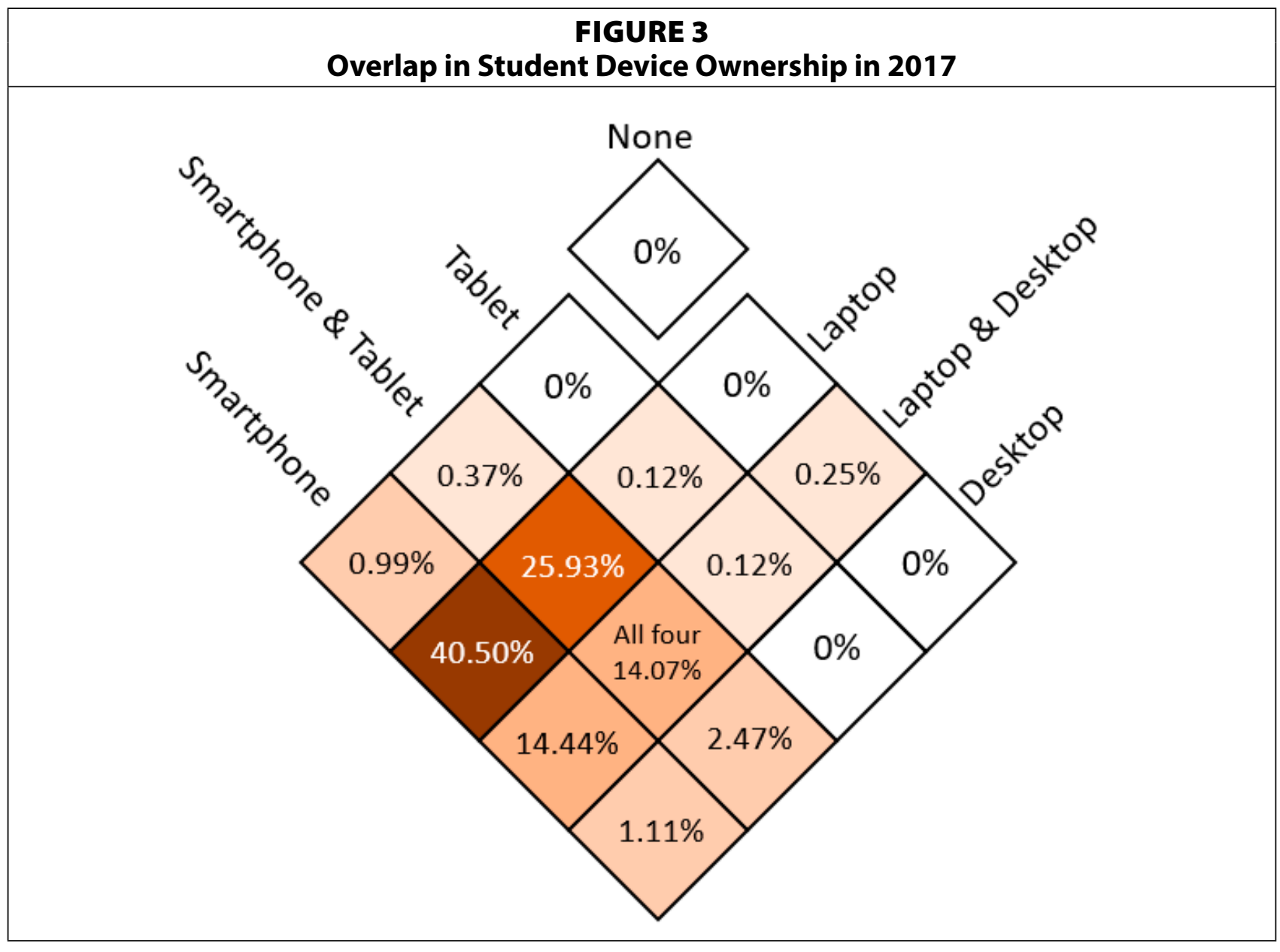

Despite almost total ownership of smartphones, students showed relatively low interest in library services optimized for these devices. Of the nine specific services proposed in the survey, all had less than 14.0 percent selection by respondents. The most popular choice was Search for library books (13.5\%). The next two most popular choices both related to user accounts: Renew books you have checked out (13.4\%) and Receive reminders when books are due (13.2\%).

\section{Social Media}

With regard to social media usage by platform (see figure 4), 83.9 percent of respondents reported use of Facebook, but almost half (44.5\%) had no interest in library services on this platform; when asked what library services might interest them, one student selected Other and wrote in, "Students don't really use facebook [sic]." 


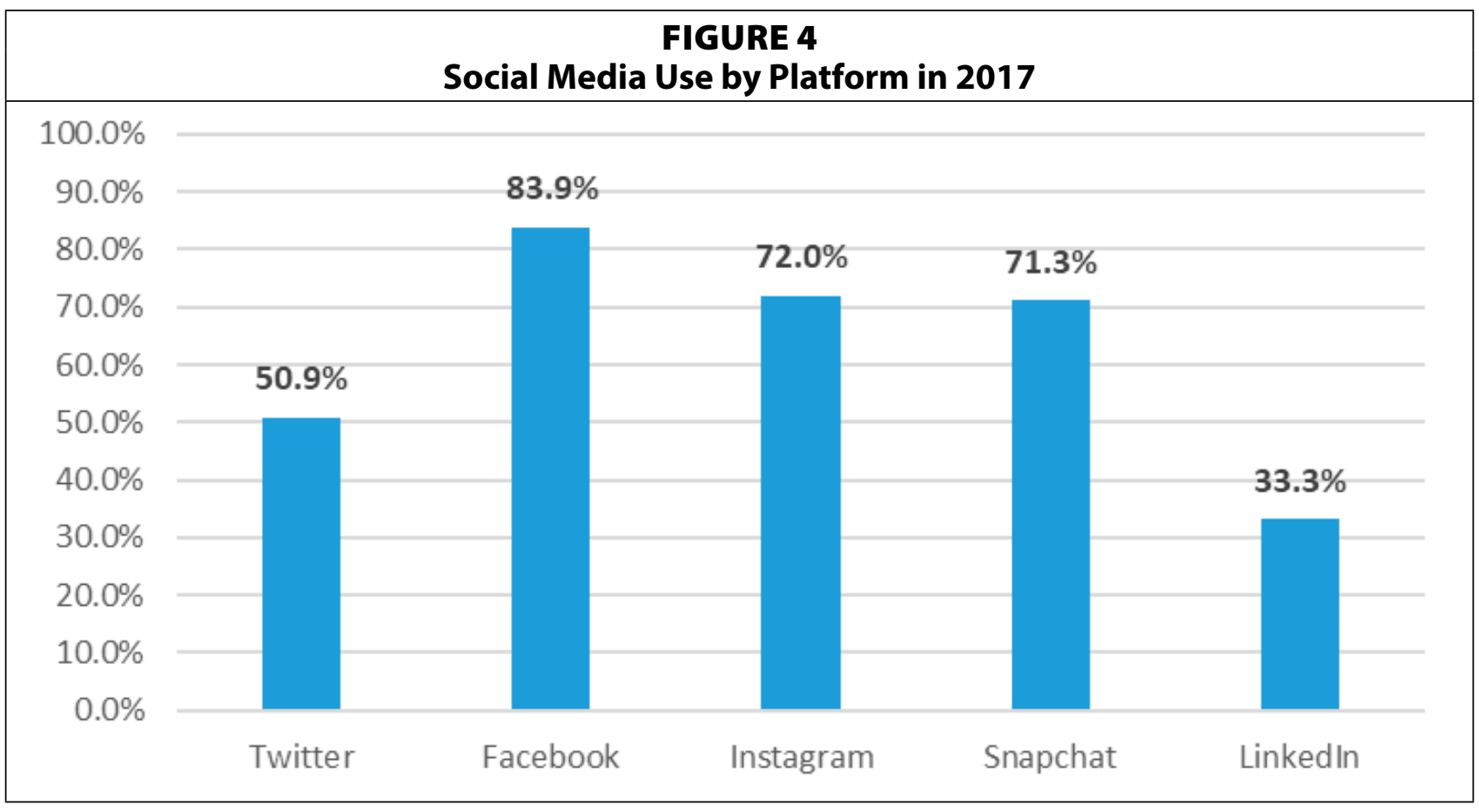

Figure 5 details the responses of those who were interested in engaging with the library by platform; the two types of engagement, abbreviated in the figure, were "Ask questions" and "Follow updates on library news, events, and resources."

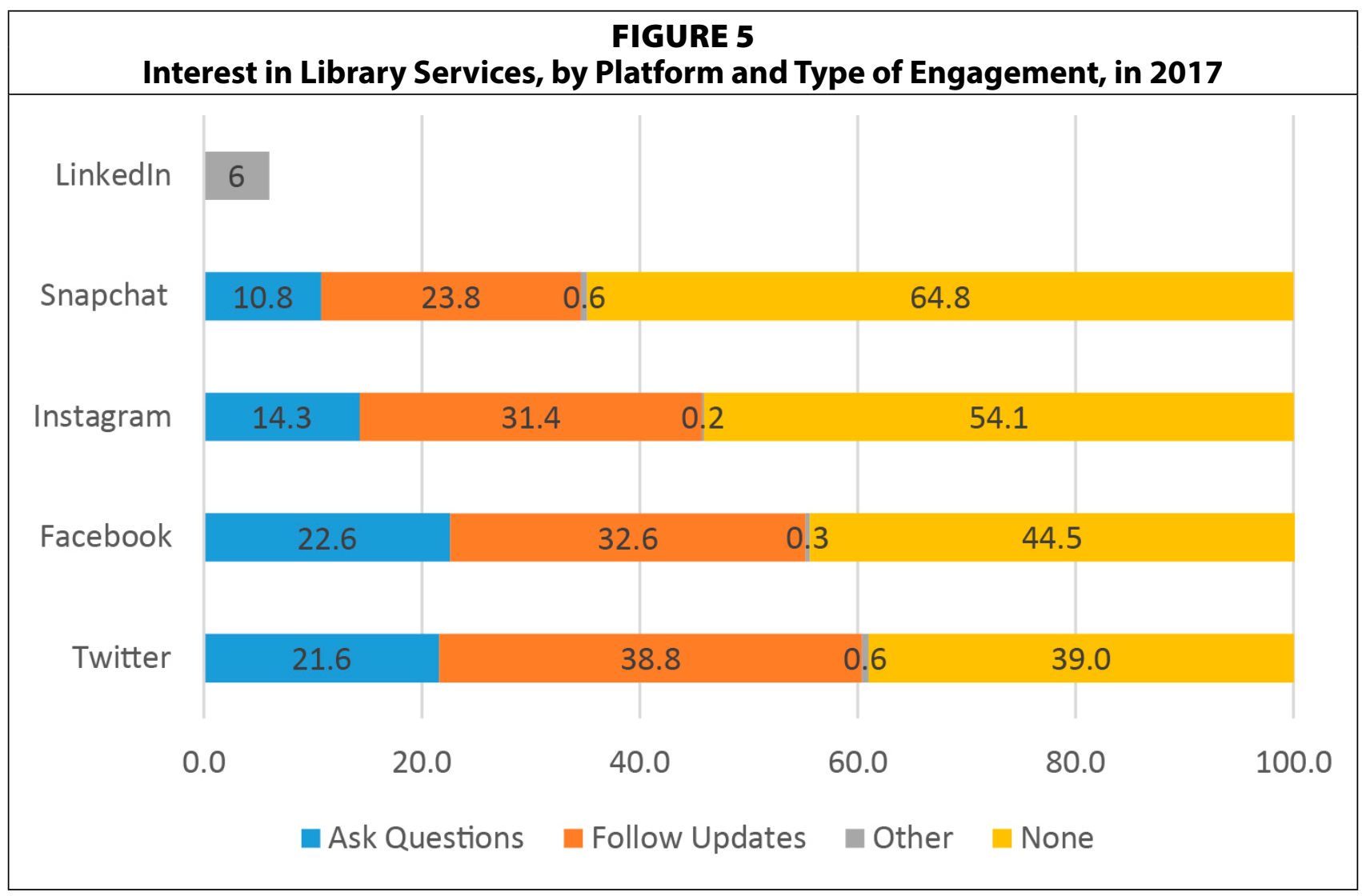


Looking at how students use social media, among Facebook users, 37.2 percent report using the platform for posting and following others equally, while more than half $(57.4 \%)$ report predominantly following other users and 5.4 percent predominantly post their own messages. Facebook use was consistently high across all colleges (see figure 6), with only 8.3 percent difference between the highest adoption ( $87.5 \%$ in College of Education) and the lowest adoption (79.2\% in College of Fine Arts \& Mass Communication).

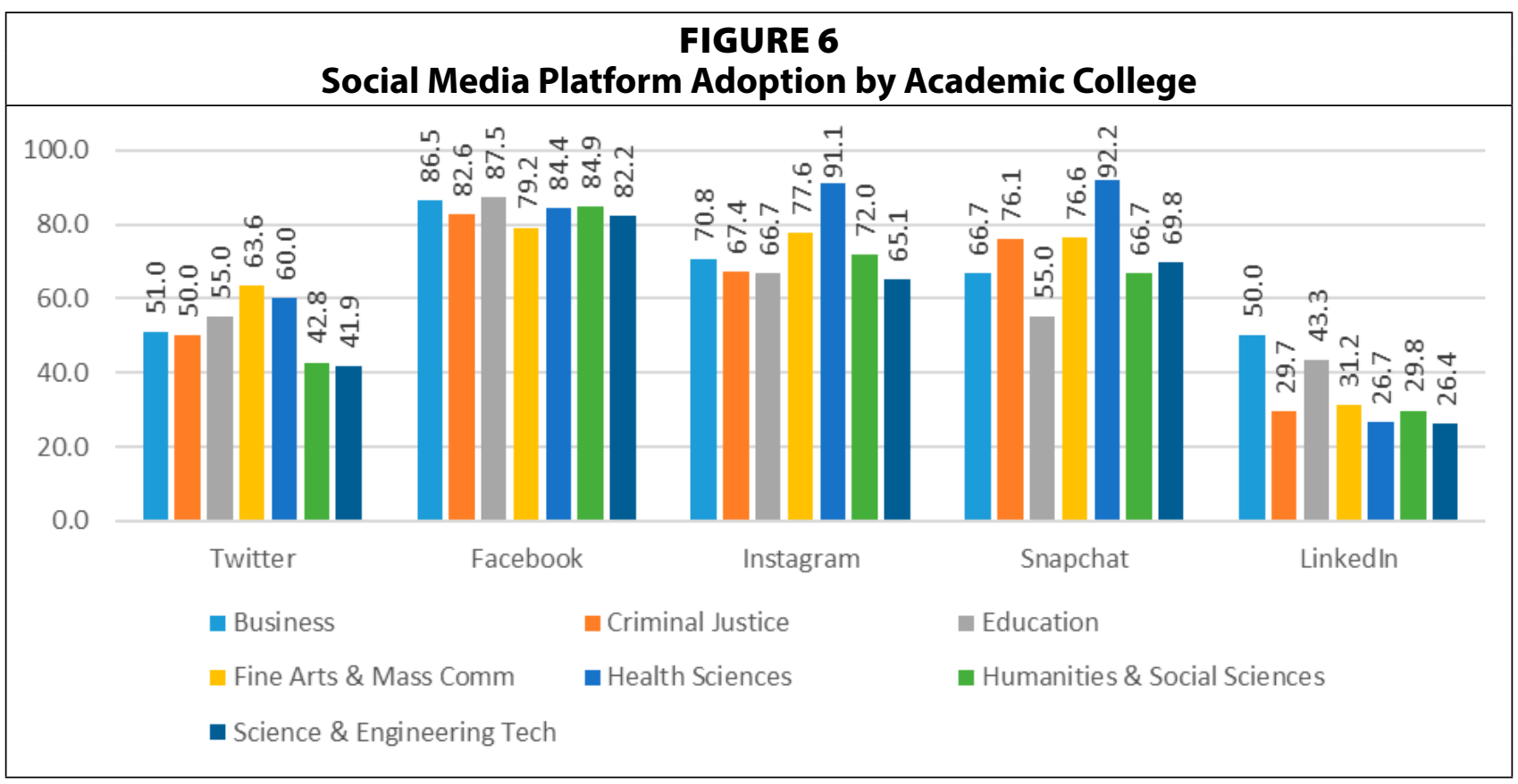

Use by student classification (see figure 7) showed an interesting "wave" trend, with the lowest adoption $(71.0 \%)$ among freshmen, increasing through the other undergraduate classifications, but then dropping off again with master's students, only to rise once again among doctoral students to 88.9 percent.

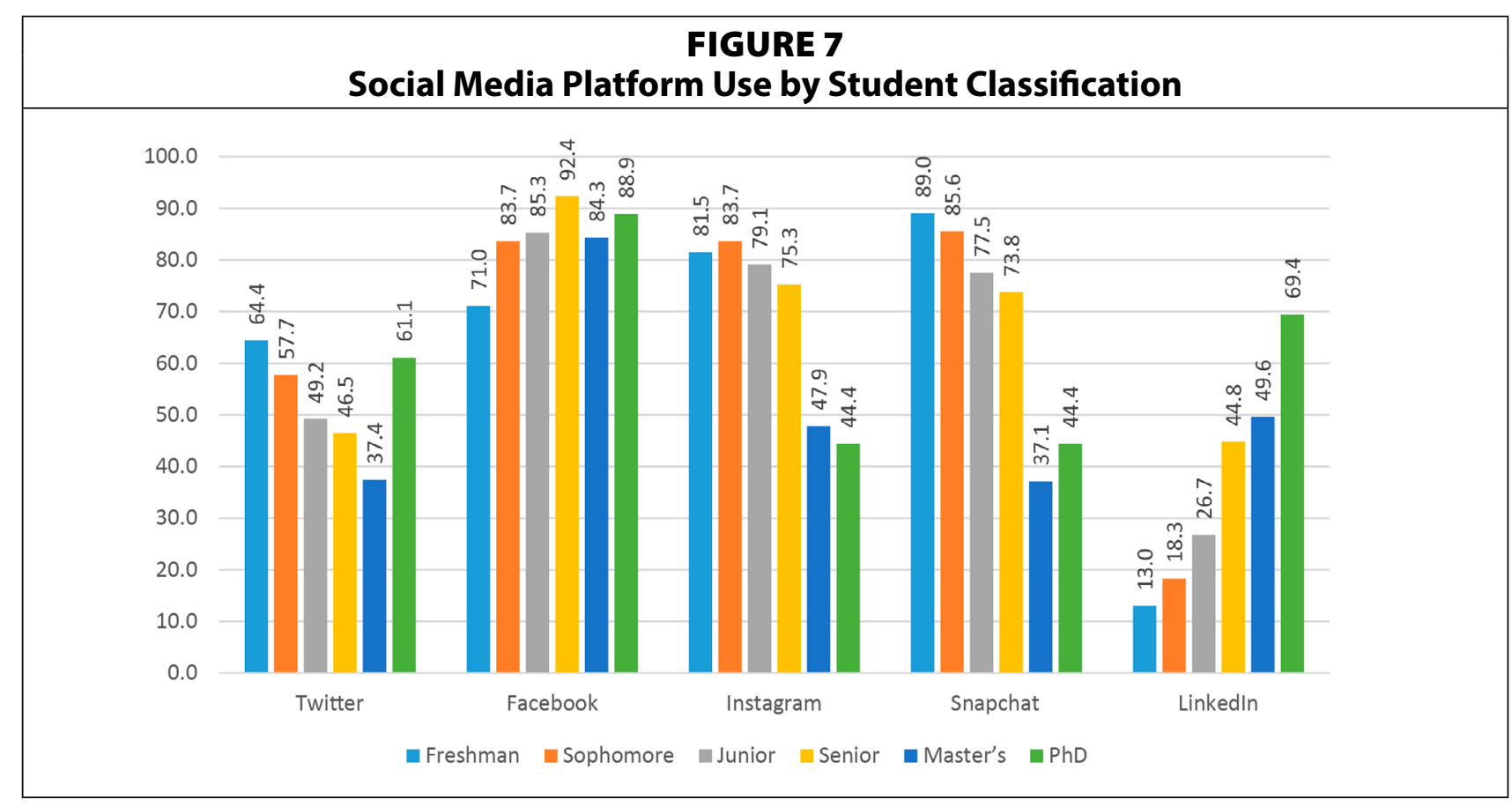


In the 2017 study, Twitter is used by about half (50.9\%) of respondents (see figure 4), representing continual growth in Twitter usage (see figure 8 ). Of the current users, 39 percent show no interest in library services, leaving 61 percent interested in some form of engagement. This measure of students interested in library services on Twitter has also increased over time.

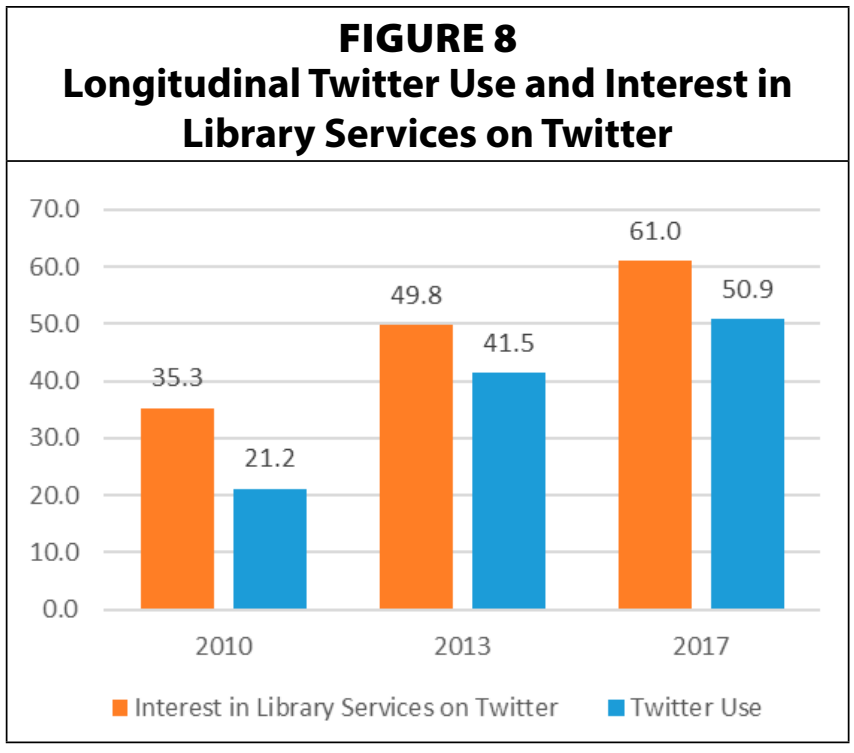

Among current Twitter users, more than half $(53.1 \%)$ report using the platform for posting and following others equally, while 42.0 percent predominantly follow other users, and only 4.9 percent predominantly post their own messages (see figure 9). Among SHSU colleges, Twitter saw its highest adoption in the College of Fine Arts $\&$ Mass Communication (see figure 6) and its lowest adoption in the College of Science \& Engineering Technology. By student classification (see figure 7), freshmen were the largest group of Twitter users (64.4\%), followed by PhD students (61.1\%); master's students represented the smallest group of users $(37.4 \%)$. As classification rose from freshmen to $\mathrm{PhD}$, more users tended toward one predominant activity, either posting or following, but were less likely to engage in both equally; for example, whereas 62.8 percent of juniors posted and followed equally, only 27.3 percent of PhD students did so, gravitating instead toward mostly following (59.1\%). A smaller portion of PhDs mostly posted (13.6\%), but that was still the highest reporting of that type of engagement among all classifications, with the lowest rate of predominantly posting occurring among freshmen (3.2\%).

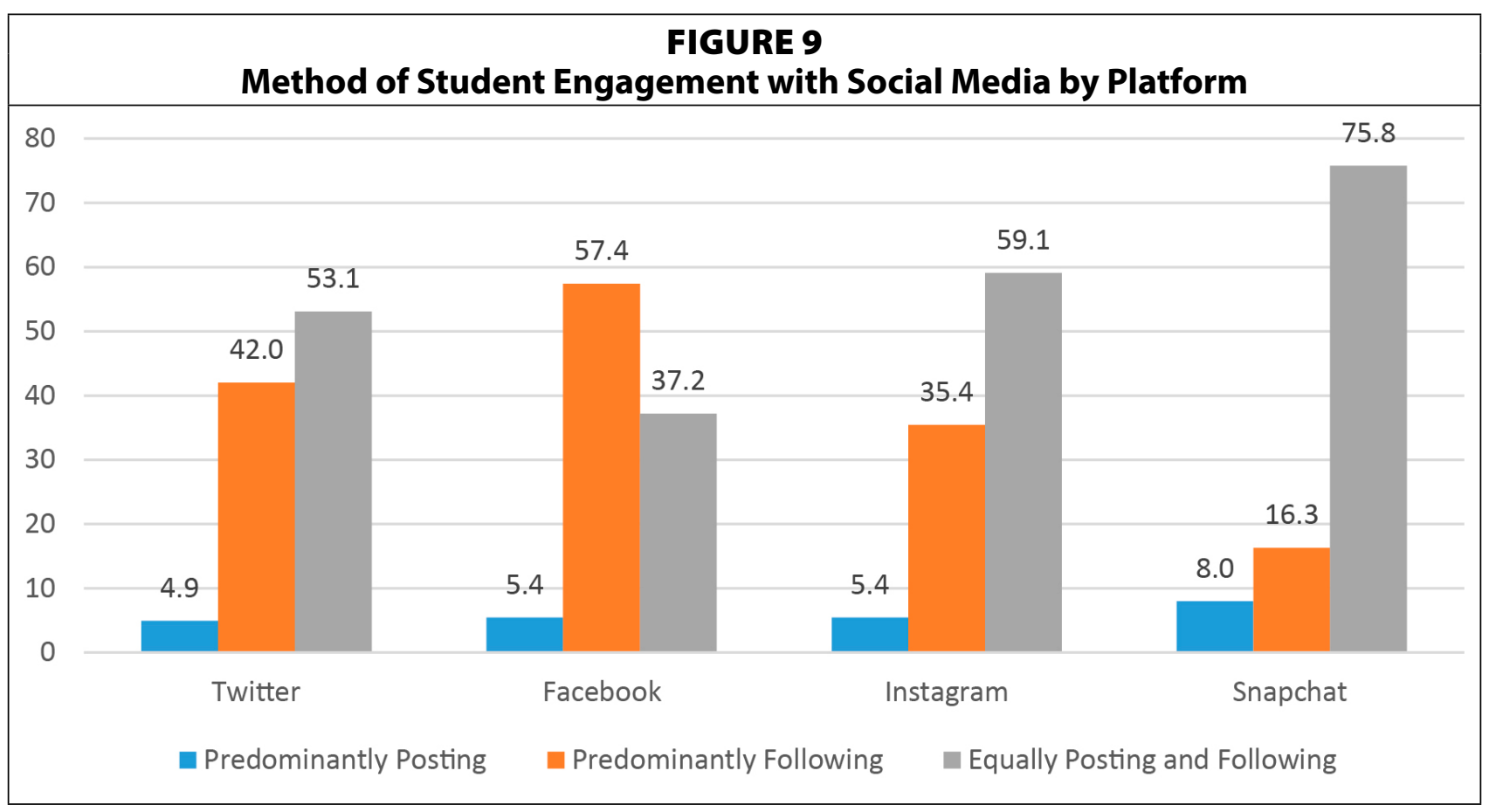


A majority of respondents $(72.0 \%)$ reported using Instagram (see figure 4). Slightly more than half of these users (54.1\%) expressed no interest in library services on Instagram. The other 45.9 percent of users showed interest in library engagement, as detailed in figure 5. Among Instagram users, 59.1 percent report posting and following equally on the platform, while 35.4 percent predominantly follow others and 5.4 percent predominantly post their own messages (see figure 9). The College of Health Sciences represented the most Instagram use $(91.1 \%)$, nearly 30 points higher than the lowest-use college, Science and Engineering Technology (65.1\%; see figure 6). Instagram use was consistently high among undergraduate students, but significantly lower among graduate students (see figure 7).

Snapchat is currently used by 71.3 percent of respondents (see figure 4), most of whom $(64.8 \%)$ have no interest in library services using Snapchat. Among Snapchat users, a whopping 75.8 percent report equally posting and following on the platform, while only 16.3 percent predominantly follow other users and 8.0 percent predominantly post their own messages. Snapchat saw a steep 37-point difference in usage between the highest-use college (Health Sciences, $92.2 \%$ ) and the lowest-use college (Education, 55.0\%; see figure 6). The difference by student classification was similarly stark (see figure 7), with nearly 52 points between the student classification with highest use (freshmen, 89.0\%) and the classification with lowest use (master's, 37.1\%).

Use of Facebook, Twitter, Instagram, and Snapchat was primarily for Recreation/Entertainment $(66.5 \%, 66.2 \%, 80.1 \%$, and $89.7 \%$ respectively), as opposed to much lower use for Education or Work purposes. Write-in comments regarding the reasons for use of these four platforms reflected a dominant theme of staying in touch with family and friends.

Snapchat, Instagram, and Twitter saw a majority of respondents $(75.8 \%, 59.1 \%$, and $53.1 \%$ respectively) who equally post and follow other users, rather than primarily just following others (see figure 9). Facebook alone saw a reversal in the proportion of these activities, with a majority of students (57.4\%) only following others. Despite this variation in the active or passive nature of use, Snapchat, Instagram, Twitter, and Facebook saw significant use either Frequently (more than 5 times per day) or Daily (see figure 10).

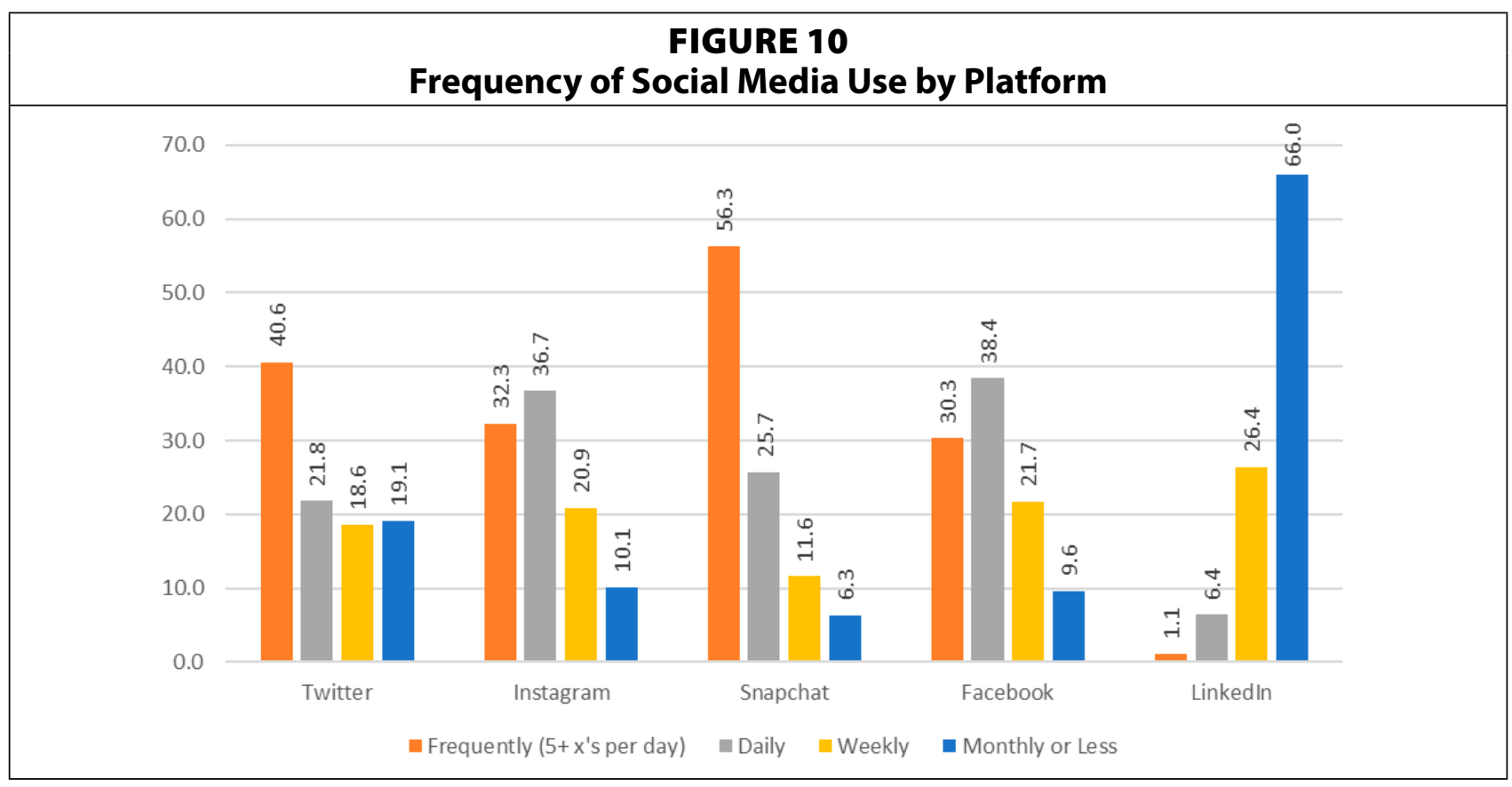




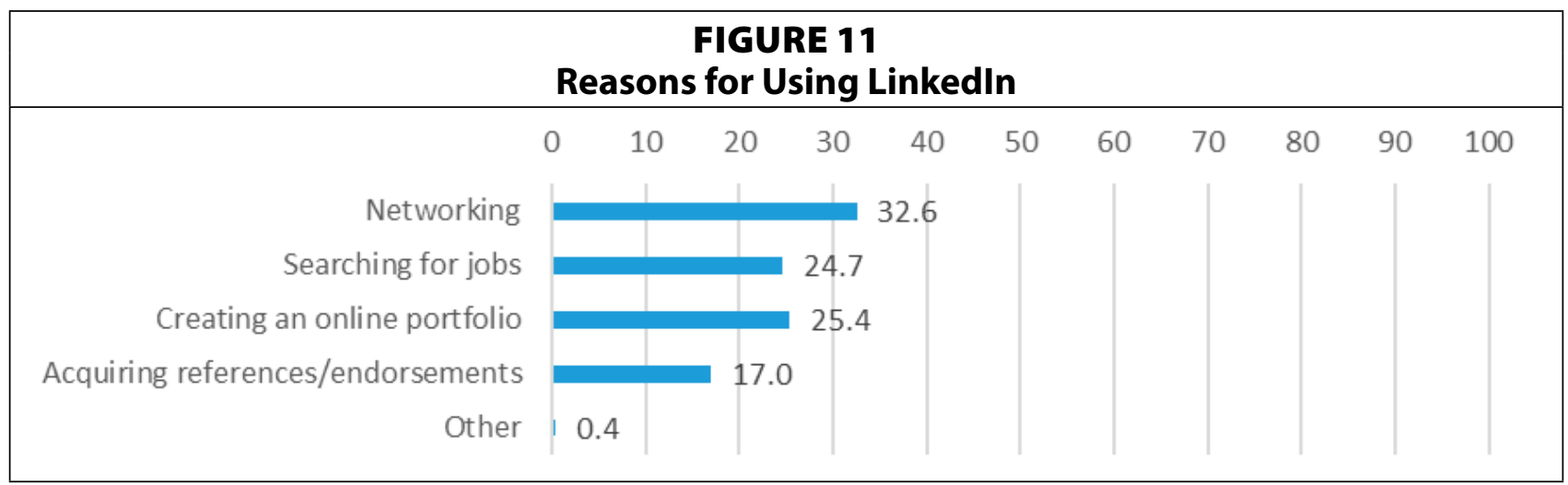

In addition to the four social media platforms that were primarily investigated, the LinkedIn platform was added to the 2017 iteration of the survey, primarily because of potential interest in the platform among other campus constituents, such as Marketing and Career Services. The majority (66.7\%) of survey respondents indicated that they did not use LinkedIn (see figure 4). When the data was analyzed by college affiliation, LinkedIn saw the greatest rate of adoption in the College of Business (50.0\%), followed by the College of Education (43.3\%; see figure 6). When responses were compared on the basis of student classification, adoption of the LinkedIn platform showed a steady increase from freshmen $(13.0 \%)$ through $\mathrm{PhD}(69.4 \%)$, as shown in figure 7 . However, more than 66 percent of students reported using LinkedIn only monthly or even less often (see figure 10).

Among those who did report using LinkedIn, 61 percent reported using it for Work, nearly double the use for Education (32.4\%) and vastly higher than use for Recreation/Entertainment (5.9\%). Among specific reasons for use, Networking was the most popular (see figure 11); write-in responses for Other Uses $(0.7 \%)$ were all in a similar vein: "Read articles," "Publish," and "Industry information via groups/blogs."

When LinkedIn usage was compared across student classifications (see figure 12), Networking was less likely among freshmen and sophomores ( $27.1 \%$ and $25.8 \%$, respectively), but

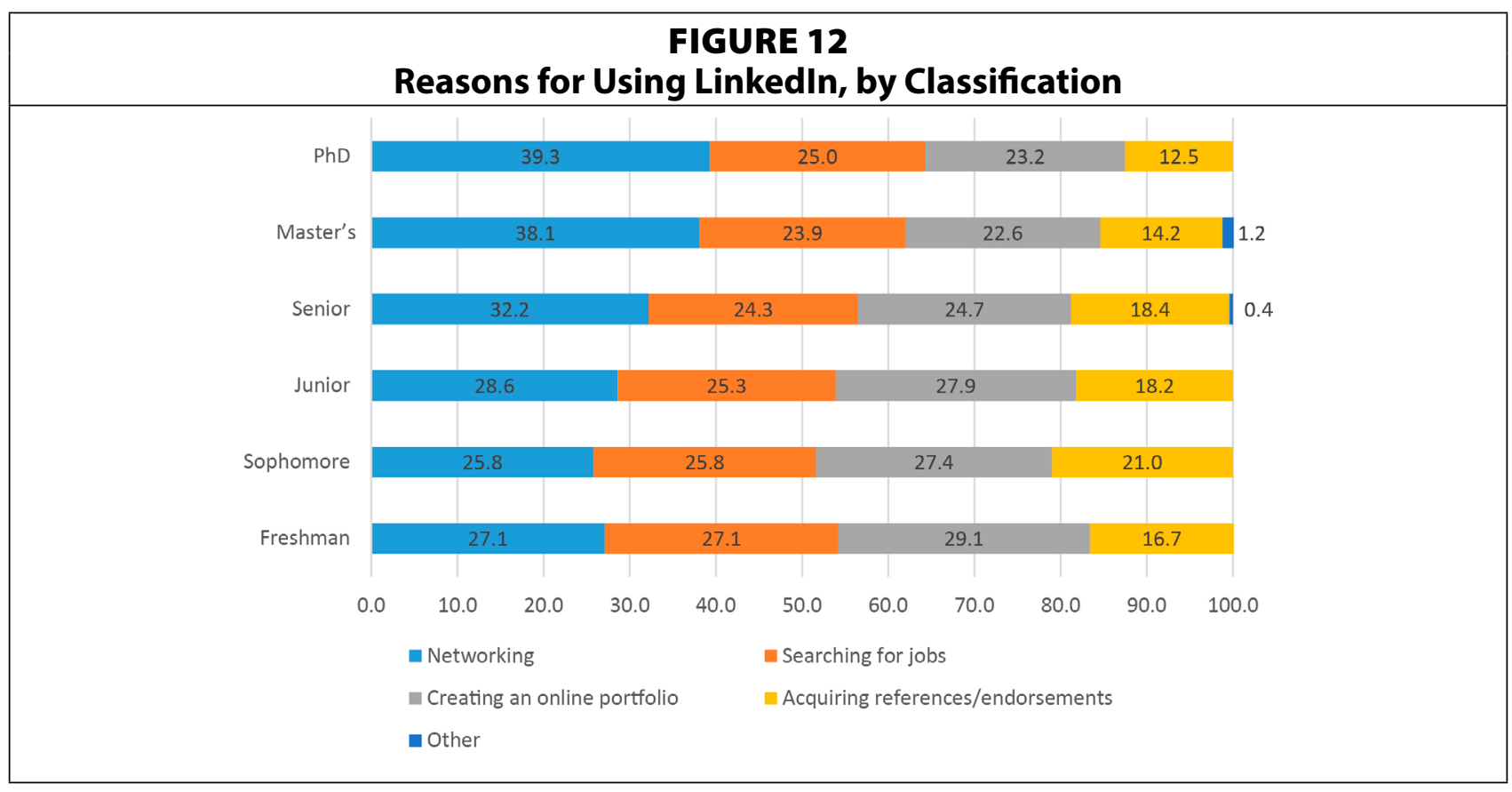




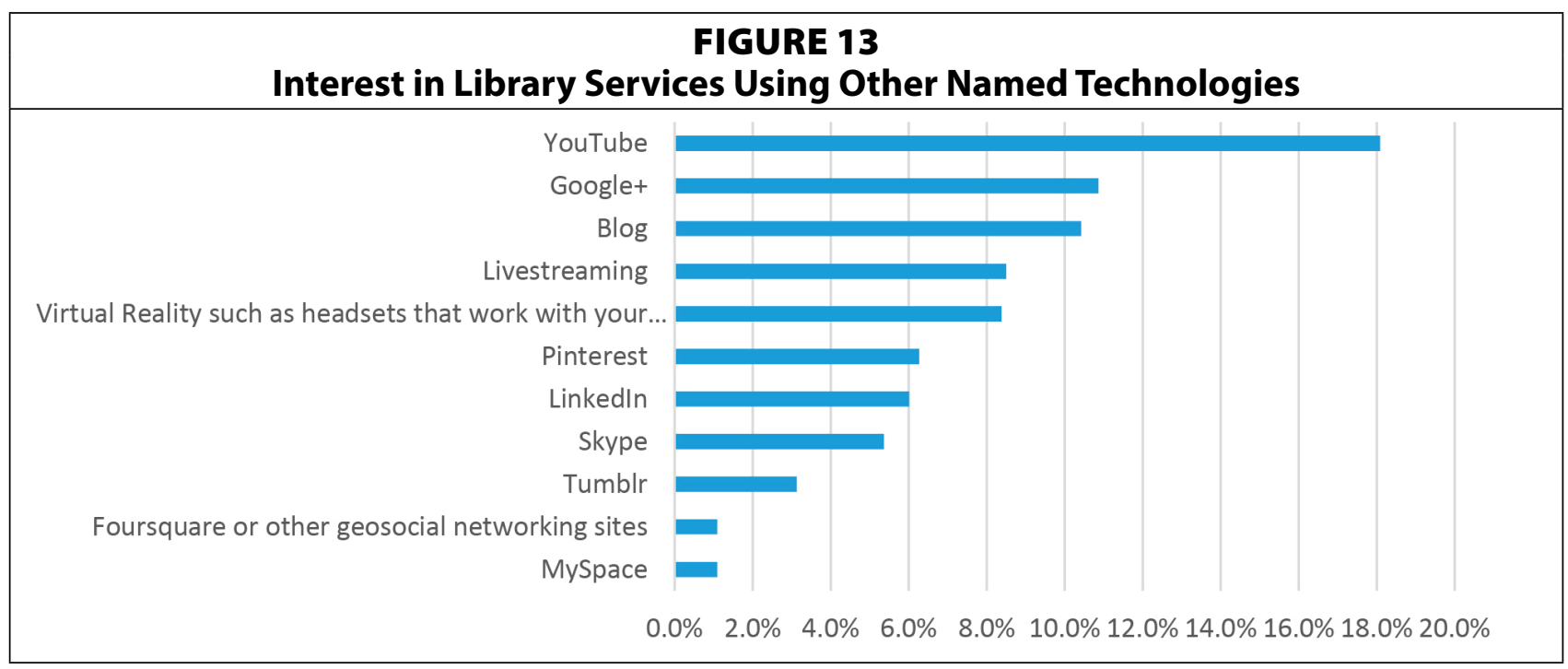

then increased steadily until $\mathrm{PhD}$ level (39.3\%). Freshmen were somewhat more likely to make use of the platform for Creating an online portfolio (29.2\%), while Acquiring references seemed to peak at the sophomore level (21.0\%) and then decline gradually through $\mathrm{PhD}(12.5 \%)$.

Although the survey did not include a question to gauge interest in specific library services on LinkedIn, the broad question "Would you be interested in library services that use any of these technologies?" included LinkedIn as an option, and only 6 percent of respondents indicated any interest (see figure 13). LinkedIn ranked seventh out of 11 proposed technologies; only four choices rated lower interest than LinkedIn: Foursquare (1.1\%), MySpace (1.1\%), Tumblr $(3.1 \%)$, and Skype $(5.4 \%)$.

When participants were asked to "Please share other forms of technology you think the library should use to provide services," numerous suggestions were written in; figure 14 illustrates some

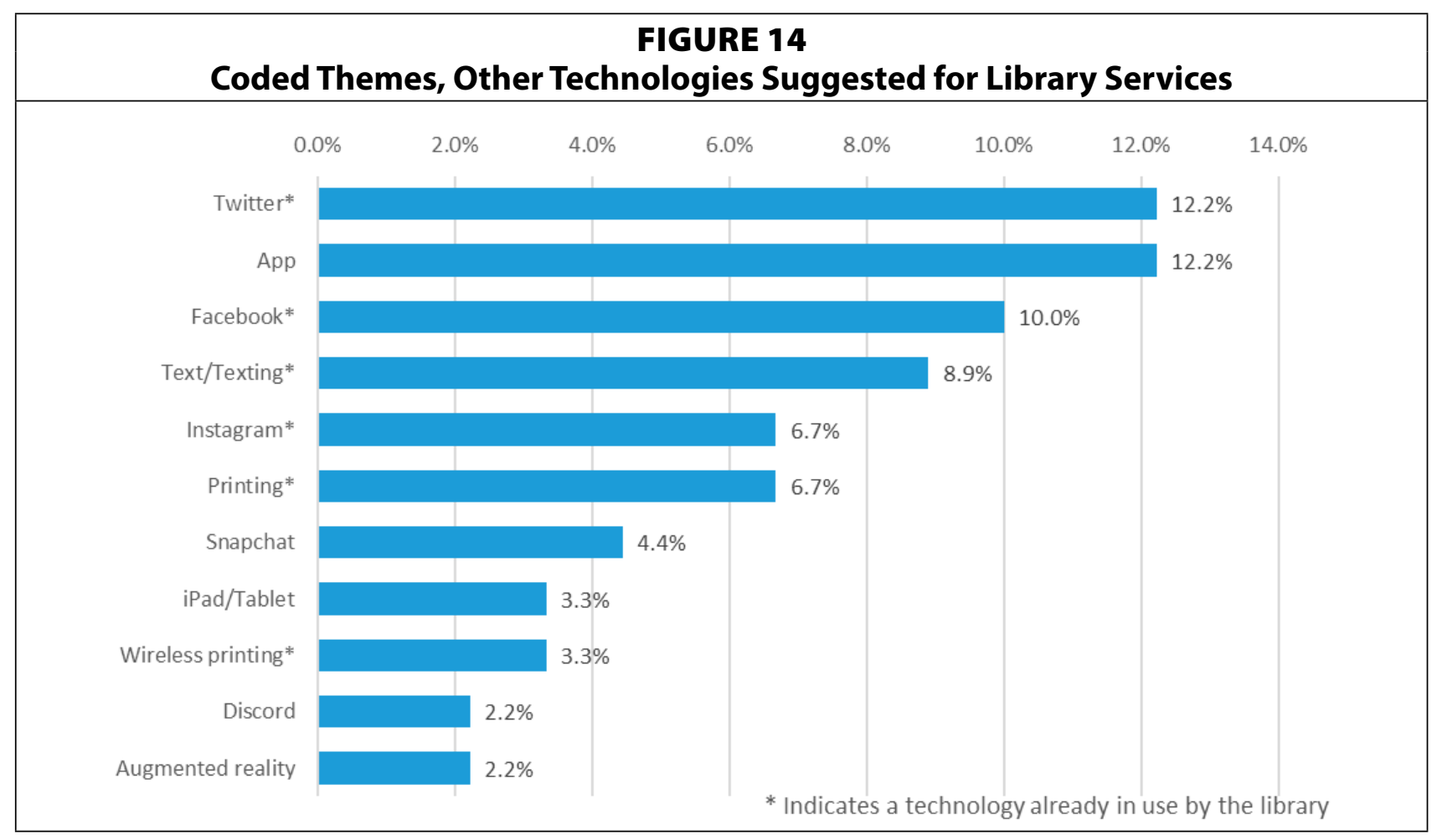


of the coded themes. Every technology followed by an asterisk (*) is already being used or provided; in fact, the library is already leveraging five of the top six technologies recommended by student respondents. For example, although the library has been operating a Twitter account since 2009, 11 respondents suggested that the library should use Twitter, suggesting a discovery and marketing issue. Comments included: "I highly recommend using a twitter [sic] account with library updates as it is widely used by a variety of the students on campus," and "REALLY look into twitter [sic] and letting people know that you have a twitter [sic]."

\section{Discussion}

The survey was organized in two discrete sections - devices and social media - so this discussion will address these sections individually. Each section addresses the findings, their implications, and how the SHSU library will modify or reevaluate services based on these findings.

\section{Devices}

The majority (57.8\%) of students report using a campus desktop computer at least once a week, which seems to justify the continued support of the library's computer lab areas. SHSU librarians anecdotally observe that these areas are constantly in high demand, but having additional evidence to support this conclusion is advantageous. In contrast, the low number who report borrowing library laptops $(7.8 \%)$ could potentially raise questions about the value of the library's laptop lending program, yet this number surprised the researchers, who anecdotally perceived the service as heavily used. Actual usage statistics for the library's eight circulating laptops recorded 829 uses in calendar year 2017, but it is still unclear whether this represents widespread use or regular use by only a few people. Respondents may not have associated the question with the library's service since the question was phrased as "How often do you borrow a campus laptop?" rather than a "library laptop." This study's findings will need to be coupled with a continuing analysis of usage statistics and an evaluation of marketing efforts before the library considers changing the laptop-lending program.

When this survey was first conducted at the university in 2010, the iPad was still on the cusp of release. The device was then incorporated into the 2013 iteration of the survey, and the researchers noted that "student ownership increased from none to about one-third of the student population in just three years." 58 The disruptive nature of the iPad's debut seemed to suggest that it would transform the academic computing landscape, but the 2017 data suggests otherwise. Between 2013 and 2017, the number of students reporting use of an iPad or other tablet increased by only 9.2 percent. Interested nonusers decreased by 31.4 percent, and uninterested nonusers increased by 22.2 percent. In other words, interest has significantly decreased. This 2017 survey data matches up with 2017 ECAR study, which saw a 7 percent drop in tablet ownership compared to the previous year and found that 90 percent who "do not own a tablet told us that they have no intention on purchasing one." ${ }^{59}$ At this time, the researchers can only speculate about why interest in tablets has dropped off so precipitously among the student population.

Although the decline in tablet interest was unexpected, the decline in e-reader usage and interest came as no surprise. This result mirrors national trends: the Pew Research Center reports a decline in e-reader ownership across the general population between 2013 and $2015 .{ }^{60}$ As e-book apps for tablets and smartphones have proliferated and incorporated more robust features, the streamlining of multiple functions in one device seems to have triumphed over ownership of a standalone device dedicated to electronic reading. 


\section{Social Media}

To some extent, the researchers were surprised by the high number of participants reporting use of Facebook, and, in particular, the number reporting use once or more daily, because so many other sources-including the university's IT and marketing divisions-perceive that students are not on the Facebook platform. Yet, according to the Pew Research Center, Facebook is popular among all demographic groups: For ages 18-24, 80 percent used Facebook (despite some of these users deleting the app ${ }^{61}$ ), followed by Snapchat at 78 percent, Instagram at 71 percent, and Twitter at 45 percent. $^{62}$ These numbers are very close to the current survey results (Facebook, 83.9\%; Instagram, 72.0\%; Snapchat, 71.3\%; and Twitter, $50.9 \%)$.

An anecdotal evaluation of respondent write-in comments may suggest a possible explanation: many students keep a Facebook account for staying up to date with family and friends. Thus, the high self-reported use in the survey may be reflective of private, interpersonal use, perhaps because some family members have not adopted other platforms.

In contrast, the low statistics reported by other campus divisions may reflect low student "following" of and engagement with business and organizational pages on the Facebook platform. Although the researchers do not have access to the pre-2013 engagement rate data, other research suggests that the Newsfeed algorithm changes in 2013 negatively affected the reach and engagement of organizational Facebook pages. ${ }^{63}$ Usage was skewed in favor of following others compared with either posting or posting and following; as Facebook's numbers differed starkly from the other platforms in this regard, it may indicate that students employ Facebook as a more passive and less engaged medium. Meanwhile, the very low number $(1.6 \%)$ of current nonusers with an interest in using Facebook suggests that the platform has more or less reached its peak saturation potential with this demographic, and it may have little opportunity for growth in the university student population. In light of declining interest in Facebook among young adults and the algorithmic changes that reduced the visibility of libraries' posts, the library should periodically review these and other trends to justify continued investment in this platform.

A longitudinal analysis of Twitter usage since 2010 indicates that SHSU students have adopted this platform at increasing rates, and their expressed interest in library services on this platform have seen a corresponding increase. The library's approach to managing its Twitter profile has evolved over time: The platform began in 2009 as a "push-only" communication tool. When the library launched a Facebook page in 2010, content was mirrored across both platforms until 2012, when greater differentiation in use began, and the library's Twitter profile began to encourage two-way communication. In 2016, the management of library social media shifted from one individual to a committee, and the Twitter feed has seen an increase in community engagement with these changes. Although room still exists for improvement and greater user engagement, the study's findings validate our continued investment in pursuing meaningful interactions with students on this platform.

The library did not create an Instagram account until fall 2016, with the first post on September 26, 2016. Because the library's Instagram presence is relatively recent, it will be valuable to continue to reassess students' self-expressed interest as well as actual engagement with the library on Instagram to determine the success and value of continuing with this platform. Meanwhile, Snapchat users were distinctly less interested in library services compared to other platforms. The low reported interest in asking the library questions via 
Instagram and Snapchat is unsurprising, since these predominantly visual platforms are not necessarily designed with Q\&A interaction in mind.

The Pew Research Center found that "Some 78\% of 18- to 24-year-olds use Snapchat, and a sizeable majority of these users $(71 \%)$ visit the platform multiple times per day." ${ }^{64}$ When the current survey of SHSU students was examined for only 18- to 24-year-olds, 84.5 percent of them reported using Snapchat; however, while 88.8 percent of that group reported use at least once daily, only 63.2 percent reported Frequent use (more than five times daily), lower than the 71 percent reported by Pew. However, this discrepancy could be explained simply by the present survey's specification of more than five times per day, versus Pew's broader phrasing of several times per day.

The library presently has no Snapchat presence. Snapchat allows users to communicate though video, voice and video calls, Bitmoji, text, photo, stickers, and by group via Snapchat snap. ${ }^{65}$ In 2013, Snapchat introduced Snapchat Stories, which allows users to create 10-second snaps (a storyline) that can be shared for 24 hours with friends and followers. ${ }^{66}$ However, the primary attributes of Snapchat and Snapchat Stories are quite comparable to both Instagram Stories, introduced in 2016, and Facebook Stories, launched in 2017. Instagram Stories permits users to publish stories consisting of images, text, or videos, which are available for up to 24 hours. ${ }^{67}$ Facebook Stories offers exclusive filters and the ability to cross-post among platforms ${ }^{68}$ Given the relative similarity among Instagram, Facebook, and Snapchat Stories' primary features, and the investment of time and labor required to launch and maintain a presence on additional social media platforms, the survey's findings seem to validate the library's decision to continue its existence on Facebook and Instagram rather than venture into Snapchat at the present time.

A segment of the student population is clearly leveraging LinkedIn for professional networking and self-promotion, but it sees much less use and a significantly lower frequency of use compared to other platforms. The low freshman use of LinkedIn, increasing in conjunction with student classification and advancement, seems unsurprising to the researchers; this platform would be of greater interest to students as they near completion of a degree and begin to think more seriously about job prospects. Although the researchers envision the potential benefits of the campus using LinkedIn as a tool to support students' professional networking, promotion of the skills gained in their education, and alumni connection to the university, its usefulness as a library marketing and engagement resource is much less clear. The survey's findings of low student adoption and lower student interest in library services support the conclusion that, at this time, the library does not need to commit resources to inventing a use for this platform.

When evaluating students' social media platform use by academic college, there are indications that it may be affected by the platform adoption of the colleges themselves. For example, the greatest use of Twitter occurs among students in the College of Fine Arts \& Mass Communication; that college launched its official Twitter presence in February of 2013. The lowest use of Twitter occurs among students in the College of Science \& Engineering Technology, which did not launch an official Twitter presence until November 2018. Adoption and promotion of a platform by a college may influence a student in that college to at least join that platform, if only to follow updates from their academic program. This may explain the discrepancies seen between colleges more fully than an assumption that different majors have inherently different social media preferences. If the researchers identify continuing trends of 
the various colleges gravitating toward different platforms, however, then they might consider targeting those populations more directly with posted content.

Approximately 13.2 percent of students indicated that they would like to receive notifications by cell phone to remind them when books are due. Currently, the library does not provide this service, but an additional module could be purchased from the Integrated Library System (ILS) vendor for an added cost, which would specifically allow for text-message notifications. For this type of service, the library would have to balance the requests of a small patron group against a limited budget that faces many other demands. Furthermore, because of the question's phrasing, it is unclear whether students imagine these cell phone notifications coming via text message or another form, such as push notifications from an app-before investing monetarily in a tool, further investigation may be warranted to ensure that the result would actually meet user expectations.

When asked about other forms of technology the library should use to provide services, the participants named several options that are already available, such as social media (Facebook, Twitter, and Instagram), texting reference questions, and even an online catalog. All of these services are available on the library's website, and some are shown in library instruction sessions. Despite increased marketing since the 2013 study, current data indicates that the library needs to pursue additional avenues of promoting the resources and services available.

\section{Conclusion}

This study focused heavily on student social media usage and engagement with the library on these platforms. Within the hardware section, students continue to identify needs for the library to offer laptops, computers, and printers. Interest in tablets continues to decline, so it is unlikely the library will invest in providing these devices to students in the near future.

In analysis of the results, the researchers were surprised to find that, despite information indicating students did not use Facebook, a high number do have Facebook accounts, thus perhaps justifying a continued library presence on that platform. Conversely, the data confirmed the researchers' preliminary anecdotal assumptions that developing a presence on Snapchat or LinkedIn would not be an efficient use of time or resources, since a high percentage of students indicated little to no interest in engaging with the library on those platforms.

Because students are generally interested in following, if not also interacting with, the library on certain social media platforms (Twitter, Instagram, Facebook), this study confirms the library's current allocation of personnel time in maintaining an institutional presence and creating digital content for those platforms. Studying local users continues to be crucial. While not all of this study's findings may be directly pertinent to other libraries' populations, it can provide a starting point for similar institutions regarding what preferences to investigate.

\section{Author Contributions According to CRediT ${ }^{69}$ \\ Project Administration: Elkins \\ Conceptualization: Owens \\ Methodology: Elkins, Hwang, Kim, Manolovitz, Mueller, and Owens \\ Validation: Hwang}

Formal Analysis: Elkins, Hwang, Kim, Manolovitz, Mueller, and Owens

Investigation: Elkins, Hwang, Kim, Manolovitz, Mueller, and Owens

Writing - Original Draft: Elkins (Methodology), Hwang (Discussion, supporting), Kim (Literature 
Review, equal; Discussion, supporting), Manolovitz (Literature Review, equal), Mueller (Introduction; Conclusion; Discussion, supporting), and Owens (Results; Discussion, lead)

Writing - Review E Editing: Elkins, Hwang, Kim, Manolovitz, Mueller, and Owens Visualization: Owens

The authors are grateful to Stacy Johnson, Assistant Professor, SHSU, for her assistance in reviewing and copyediting this paper prior to submission.

\section{Notes}

1. Andrew Richard Albanese, "Google Is Not the Net: Social Networks Are Surging and Present the Real Service Challenge-and Opportunity-for Libraries," Library Journal 131, no. 15 (September 15, 2006); Michael E. Casey and Laura C. Savastinuk, Library 2.0 : A Guide to Participatory Library Service (Medford, NJ: Information Today, 2007); Meredith G. Farkas, Social Software in Libraries: Building Collaboration, Communication, and Community Online (Medford, NJ: Information Today, 2007); Cris Ferguson, “Technology Left Behind-Making Friends Online: Library Use of Social Networking Services," Against the Grain 19, no. 3 (June 2007): 86-87; Stacey Greenwell and Beth Kraemer, "Internet Reviews: Social Networking Software: Facebook and MySpace," Kentucky Libraries 70, no. 4 (Fall 2006): 12-16; R. David Lankes, Joanne Silverstein, and Scott Nicholson, "Participatory Networks: The Library as Conversation," Information Technology E Libraries 26, no. 4 (December 2007): 17-33, https://doi. org/10.6017/ital.v26i4.3267; Jean Vollrath, "Web 2.0 in Libraries: Assessing New Services," Southeastern Librarian 55, no. 3 (Fall 2007): 28-31.

2. Pew Research Center, "Social Media Fact Sheet," last modified February 5, 2018, https://www.pewinternet. org/fact-sheet/social-media/.

3. Pew Research Center, "Social Media Fact Sheet."

4. Aaron Smith and Monica Anderson, "Social Media Use 2018: Demographics and Statistics," Pew Research Center, March 1, 2018, www.pewinternet.org/2018/03/01/social-media-use-in-2018/.

5. Taylor \& Francis Group, Use of Social Media by the Library: Current Practices and Future Opportunities, October 2014, https://14f94x44889d2kjzh526kx45-wpengine.netdna-ssl.com/wp-content/uploads/2017/12/White-PaperSocial-Media-in-the-Library.pdf.

6. Samuel Kai-Wah Chu and Helen S. Du, "Social Networking Tools for Academic Libraries," Journal of Librarianship and Information Science 45, no. 1 (March 1, 2013): 64-75, https://doi.org/10.1177/0961000611434361.

7. Taylor \& Francis Group, Use of Social Media by the Library.

8. Gary Collins and Anabel Quan-Haase, "Are Social Media Ubiquitous in Academic Libraries? A Longitudinal Study of Adoption and Usage Patterns," Journal of Web Librarianship 8, no. 1 (January 2014): 48.

9. Smith and Anderson, "Social Media Use 2018."

10. Andrew Perrin, "Americans Are Changing Their Relationship with Facebook," Pew Research Center (blog), September 2018, www.pewresearch.org/fact-tank/2018/09/05/americans-are-changing-their-relationship-withfacebook/.

11. Smith and Anderson, "Social Media Use 2018."

12. Smith and Anderson, "Social Media Use 2018."

13. Collins and Quan-Haase, "Are Social Media Ubiquitous in Academic Libraries?" 56.

14. Ilana Kingsley, "Use of Social Media by Alaskan Libraries," PNLA Quarterly 82, no. 3/4 (September 2018): 62-72.

15. Collins and Quan-Haase, "Are Social Media Ubiquitous in Academic Libraries?"

16. Heather Howard et al., "Academic Libraries on Social Media: Finding the Students and the Information They Want," Information Technology \& Libraries 37, no. 1 (March 2018): 8-18, https://doi.org/10.6017/ital.v37i1.10160.

17. Taylor \& Francis Group, Use of Social Media by the Library.

18. Elizabeth Brookbank, "So Much Social Media, So Little Time: Using Student Feedback to Guide Academic Library Social Media Strategy," Journal of Electronic Resources Librarianship 27, no. 4 (October 2015), $232-47$.

19. Besiki Stvilia and Leila Gibradze, "Examining Undergraduate Students' Priorities for Academic Library Services and Social Media Communication," Journal of Academic Librarianship 43, no. 3 (May 1, 2017): 257-62, https://doi.org/10.1016/j.acalib.2017.02.013.

20. Brookbank, "So Much Social Media, So Little Time."

21. Brookbank, "So Much Social Media, So Little Time."

22. Brookbank, "So Much Social Media, So Little Time."

23. Zelda Chatten and Sarah Roughley, "Developing Social Media to Engage and Connect at the University 
of Liverpool Library," New Review of Academic Librarianship 22, no. 2/3 (April 2016): 249-56, https://doi.org/10.108 0/13614533.2016.1152985.

24. Chatten and Roughley, "Developing Social Media to Engage and Connect at the University of Liverpool Library,"

25. Paige Alfonzo, "Mastering Mobile through Social Media: Creating Engaging Content on Instagram and Snapchat," Library Technology Reports 55, no. 2 (2019), 5-42.

26. Alfonzo, "Mastering Mobile through Social Media," 6.

27. Alfonzo, "Mastering Mobile through Social Media," 7.

28. Alfonzo, "Mastering Mobile through Social Media," 7.

29. Alfonzo, "Mastering Mobile through Social Media," 7.

30. Alfonzo, "Mastering Mobile through Social Media," 7.

31. Melanie Chu and Yvonne Nalani Meulemans, "The Problems and Potential of MySpace and Facebook Usage in Academic Libraries," Internet Reference Services Quarterly 13, no. 1 (January 2008): 69-85, https://doi. org/10.1300/J136v13n01_04.

32. Kenneth J. Burhanna, Jamie Seeholzer, and Joseph Salem, "No Natives Here: A Focus Group Study of Student Perceptions of Web 2.0 and the Academic Library," Journal of Academic Librarianship 35, no. 6 (November 1, 2009): 523-32, https://doi.org/10.1016/j.acalib.2009.08.003.

33. Anabel Quan-Haase and Alyson L. Young, "Uses and Gratifications of Social Media: A Comparison of Facebook and Instant Messaging," Bulletin of Science, Technology \& Society 30, no. 5 (October 2010): 350-61, https:// doi.org/10.1177/0270467610380009.

34. Howard et al., "Academic Libraries on Social Media."

35. Howard et al., "Academic Libraries on Social Media."

36. Erin Dorris Cassidy et al., "Higher Education and Emerging Technologies: Shifting Trends in Student Usage," Journal of Academic Librarianship 40, no. 2 (2014), 124-33, https://doi.org/10.1016/j.acalib.2014.02.003.

37. Brookbank, "So Much Social Media, So Little Time."

38. Brookbank, "So Much Social Media, So Little Time."

39. Taylor \& Francis Group, Use of Social Media by the Library.

40. Collins and Quan-Haase, "Are Social Media Ubiquitous in Academic Libraries?"

41. Kingsley, "Use of Social Media by Alaskan Libraries."

42. Lisa Burgert, Alejandra Nann, and Lorelei Sterling, "Ventures in Social Media," Codex (2150-086X) 3, no. 1 (June 2014): 21.

43. Burgert, Nann, and Sterling, "Ventures in Social Media."

44. Brookbank, "So Much Social Media, So Little Time."

45. Stvilia and Gibradze, "Examining Undergraduate Students' Priorities"; Besiki Stvilia and Leila Gibradze, "Valued Academic Library Services Are Not Necessarily the Ones That Are Used Most Frequently, Students' Service and Social Media Communication Priorities Should Also Be Considered," Evidence Based Library and Information Practice 13, no. 3 (September 13, 2018): 94-96, https://doi.org/10.18438/eblip29463.

46. Howard et al., "Academic Libraries on Social Media."

47. Joseph Galanek, Dana Gierdowski, and D. Brooks, ECAR Study of Undergraduate Students and Information Technology, 2018, October 2018, https://library.educause.edu/resources/2018/10/2018-students-and-technologyresearch-study.

48. Galanek, Gierdowski, and Brooks, ECAR Study of Undergraduate Students and Information Technology, 2018. 7.

49. Galanek, Gierdowski, and Brooks, ECAR Study of Undergraduate Students and Information Technology, 2018,

50. D. Brooks and Jeffrey Pomerantz, ECAR Study of Undergraduate Students and Information Technology, 2017, October 2017, https://library.educause.edu/resources/2017/10/ecar-study-of-undergraduate-students-and-information-technology-2017.

51. Brooks and Jeffrey Pomerantz, ECAR Study of Undergraduate Students and Information Technology, 2017, 12. 52. Galanek, Gierdowski, and Brooks, ECAR Study of Undergraduate Students and Information Technology, 2018.

53. Galanek, Gierdowski, and Brooks, ECAR Study of Undergraduate Students and Information Technology, 2018. 10.

54. Galanek, Gierdowski, and Brooks, ECAR Study of Undergraduate Students and Information Technology, 2018,

55. S. Adams Becker et al., NMC Horizon Report: 2017 Higher Education Edition (Austin, TX: New Media Consortium, 2017), 40-41.

56. Cassidy et al., "Higher Education and Emerging Technologies: Shifting Trends."

57. Brooks and Pomerantz, ECAR Study of Undergraduate Students and Information Technology, 2017, 13.

58. Cassidy et al., "Higher Education and Emerging Technologies: Shifting Trends," 130. 
59. Brooks and Pomerantz, ECAR Study of Undergraduate Students and Information Technology, 2017, 12.

60. Pew Research Center, "Technology Device Ownership: 2015," October 29, 2015, www.pewinternet. org/2015/10/29/technology-device-ownership-2015/.

61. Perrin, "Americans Are Changing Their Relationship with Facebook."

62. Pew Research Center, "Social Media Use in 2018."

63. Brookbank, "So Much Social Media, So Little Time," 233.

64. Pew Research Center, "Social Media Use in 2018."

65. Alfonzo, "Mastering Mobile through Social Media."

66. Ginette Verstraete, "It's about Time: Disappearing Images and Stories in Snapchat," Image (E) Narrative 17, no. 4 (2016): 104-13.

67. Thiago Alexandre de Souza Silva et al., "Ephemeral Narrative Systems; Sociability Mediated by User Experience: A Case Study of Instagram Stories," IADIS International Journal on WWW/Internet 1, no. 2 (2018): $34-49$.

68. Michelle Cyca, "Snapchat, Instagram Stories, or Facebook Stories: Which Is Right for You?" Hootsuite (blog), March 28, 2018, https://blog.hootsuite.com/Snapchat-instagram-facebook-stories/.

69. CRediT is a structured taxonomy that describes the roles played by each contributor to a scholarly output: https://www.casrai.org/credit.html. 